報文

\title{
多分枝第三級カルボン酸からの界面活性剂の合成と物性
}

\author{
中辻 洋司* ・ 上野 真吾* ・ 木寺 洋介*・益山 新樹*・ \\ 岡原 光男*・川崎 宏** \\ * 大阪大学工学部応用化学科 (₹ 565 大阪府吹田市山田丘 2-1) \\ ** 出光石油化学 (株) 化成品研究所 (₹ 745 山口県徳山市新宮町 1-1)
}

\section{Synthesis and Properties of Surfactants Derived from Highly Branched Tertiary Carboxylic Acids}

\author{
Yohji NAKAtSuJI*, Shingo Ueno*, Yohsuke KiderA*, Araki Masuyama*, \\ Mitsuo OKAHARA*, and Hiroshi KAWASAKI** \\ * Department of Applied Chemistry, Faculty of Engineering, Osaka University \\ (2-1, Yamada-oka, Suita-shi, Osaka-fu, T 565) \\ ** Chemical Research Laboratory, Idemitsu Petrochemical Co., Ltd. \\ (1-1, Shingu-cho, Tokuyama-shi, Yamaguchi-ken, $\bar{\top} 745)$
}

\begin{abstract}
Several surfactants were derived from highly branched carboxylic acids, prepared by the carbonylation of isobutylene oligomers. Surface and forming properties, and wetting ability toward a felt chip were examined. Ionic surfactants such as sodium sulfonate, sodium sulfates, quaternary ammonium salts, and the betaine derivative showed good ability for lowering surface tension and excellent wetting ability. Micelle forming properties were relatively poor compared to the corresponding linear analogs. To characterize the highly branched structure of hydrophobic group in surfactants several connecting groups between the hydrophilic group and the highly branched moiety were investigated for series of sodium sulfate derivatives. Micelle forming properties improved by increase in the hydrophobicity of the connecting chains without decrease in water solubility. The esters of carboxylic acid and the poly (ethylene glycol), a nonionic surfactant, could be easily prepared and were found to have the qualities mentioned above due to their highly branched structures.
\end{abstract}

\section{1 緒言}

最近，枝分かれしたアルキル鎖をもつ第三級カルボン 酸がイソブチレンオリゴマーのカルボニル化反応によっ て工業的に安価に製造されるようになり, 各工業分野に おける利用が検討されている1)。多分枝第三級本カルボ ン酸の高度な枝分かれ構造を界面活性剂の疎水基として とらえた場合，直鎖型の対極に位置する典型的な分枝型 とみなすことができ，その特殊な構造が界面活性剤の諸 物性によ゙のような影響を与えるか興味がもたれる。以上 の観点から本研究では, 典型的な分枝型界面活性剤の特 徵を明らかにすることを目的として, 多分枝第三級カル ボン酸に諸種修飾を施すことによって対応する界面活性 剂へと誘導し, その基本的な界面物性を測定した。本研

連絡者 : 中辻洋司
究で合成した化合物 $(1 \sim 9)$ 及び参照化合物として用い た硫酸 $n$-アルキル=ナトリウム (10) の構造を Fig. -1 に示す。

\section{2 実験}

\section{$2 \cdot 1$ 試 料}

原料カルボン酸として, 出光石油化学 (株) 製の多分 枝第三級カルボン酸 ${ }^{2}$ であるエクアシッド 13 (以下 A13 上略す) (炭素数 13 のカルボン酸含量 $97.2 \mathrm{wt} \%$; 中 和価 274) とエクアシッド 9 (以下 A-9 と略す)（炭素 数 9 のカルボン酸含量 $97.8 \mathrm{wt} \%$; 中和価 350) を使用 した。

$$
\begin{aligned}
& 2 \cdot 2 \text { 合 成 } \\
& 2 \cdot 2 \cdot 1 \text { 多分枝第三級アシルクロリドの合成 }
\end{aligned}
$$

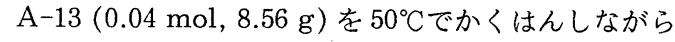


$\stackrel{\mathrm{O}}{\mathrm{C}_{12} \mathrm{H}_{25}-\mathrm{C}-\mathrm{NH}-\left(\mathrm{CH}_{2}\right)_{2}-\mathrm{SO}_{3} \mathrm{Na}}$

1<smiles>CCC(=O)OCCO[Se]N</smiles>

$3 \mathrm{a}: n=4$

$3 \mathrm{~b}: n=6$

$3 c: n=8$

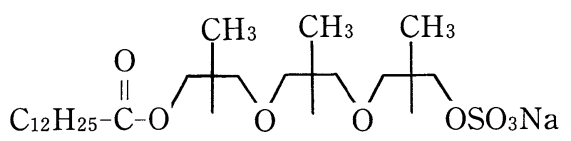

5<smiles>CCCCC[N+](C)(CCNC(=O)CCC)Cc1ccccc1</smiles>

7

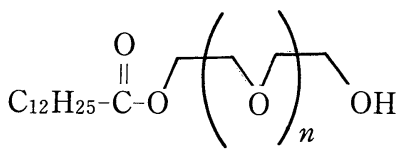

$9: n=c a .10$<smiles>[15N]O[Se]OCCOC(=O)c1ccccc1</smiles>

2 a $: n=8$

$2 \mathrm{~b}: n=10$

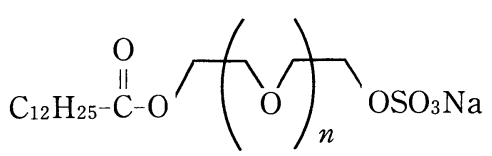

$$
4 \mathrm{a}: n=1
$$$$
4 \mathrm{~b}: n=2
$$<smiles>CCCCCOC(=O)CC</smiles>

6

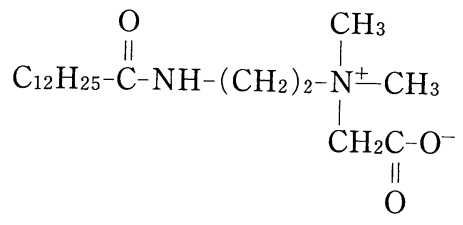

8

$$
\begin{aligned}
& \text { 10a }: \mathrm{R}=n-\mathrm{C}_{12} \mathrm{H}_{25} \\
& 10 \mathrm{~b}: \mathrm{R}=n-\mathrm{C}_{14} \mathrm{H}_{29} \\
& 10 \mathrm{c}: \mathrm{R}=n-\mathrm{C}_{16} \mathrm{H}_{33}
\end{aligned}
$$

Fig.-1 Structure of surfactants (1 9) derived from highly branched tertiary carboxylic acids and sodium linear alkyl sulfates (10).

塩化チオニル $(0.08 \mathrm{~mol}, 9.52 \mathrm{~g})$ を $30 \mathrm{~min}$ かけて滴下 した。 $50^{\circ} \mathrm{C} て ゙ ~ 2 \mathrm{~h}$ 反応後, 軽沸分を留去し, 赤茶色半 透明の粘ちょうな液体としてほぼ定量的に対応するアシ ルクロリド（以下 $\mathrm{Cl}-13$ と略す）を得た。IR スペクト ルより, 原料カルボン酸由来の $1700 \mathrm{~cm}^{-1}\left(\nu_{\mathrm{C}=\mathrm{O}}\right)$ にお ける吸収の消失と, $1780 \mathrm{~cm}^{-1}\left(\nu_{\mathrm{C}=\mathrm{O}}\right)$ における吸収に よりその生成を確認した。A-9 由来のアシルクロリド （以下 Cl-9 と略す）も同様の方法により合成した。

$2 \cdot 2 \cdot 2$ スルホン酸塩型ア二オン界面活性剂 (1) の合 成

タウリン $(0.03 \mathrm{~mol}, 3.75 \mathrm{~g})$ と水酸化ナトリウム $(0.03 \mathrm{~mol}, 1.20 \mathrm{~g})$ をメタノール $(400 \mathrm{~mL})$ に溶かし,
メタノールを留去することによりタウリンナトリウム塩 とした。Cl-13 (0.02 mol, $4.64 \mathrm{~g})$, トリエチルアミン $(0.03 \mathrm{~mol}, 3.03 \mathrm{~g})$, タウリンナトリウム塩 $(0.024 \mathrm{~mol}$, $3.53 \mathrm{~g})$ を混合し, 常温で $24 \mathrm{~h}$ かくはんした。これに 水 $(150 \mathrm{~mL})$ を加え, 1-ブタノール $(150 \mathrm{~mL}$ で 2 回 $)$ で抽出した後、1-ブタノールを留去した。IR スペクト ルから若干量のアシルクロリド及びカルボン酸の混在が 認められたので不純物の吸収が消失するまでへキサンに よるデカンテーションを繰り返し，これらを除去した。 赤橙色半透明の粘ちょうな液体として目的物 (1) (2.71 g, $40 \%$ ) を得た。IR : $1640 \mathrm{~cm}^{-1}\left(\nu_{\mathrm{C}=\mathrm{O}}\right)$; NMR (CD$\left.\mathrm{Cl}_{3}\right), \delta: 0.84 \sim 1.44(\mathrm{~m}, 25 \mathrm{H}), 3.08 \sim 3.30(\mathrm{~m}, 2 \mathrm{H}$, 
$-\mathrm{CONHCH}_{2} \mathrm{CH}_{2}-$ ), 3.58 3.70 (t, $2 \mathrm{H},-\mathrm{CONHCH}_{2}$ $\mathrm{CH}_{2}{ }^{-}$).

$2 \cdot 2 \cdot 3$ 硫酸エステル塩型ア二オン界面活性剤 $(2 ５)$ の合成

一例として $3 \mathrm{~b}$ の例を示す。へキサメチレングリコー ル $(0.04 \mathrm{~mol}, 4.72 \mathrm{~g})$, トリエチルアミン $(0.08 \mathrm{~mol}$, $8.08 \mathrm{~g}), 1,2$-ジクロロエタン $(10 \mathrm{~mL})$ を混合し，還流 条件下, Cl-13 (0.02 mol, $4.64 \mathrm{~g})$ の1,2-ジクロロエ夕 ン $(10 \mathrm{~mL})$ 溶液を $1 \mathrm{~h}$ かけて徐々に滴下しさらに $4 \mathrm{~h}$ 還流した。溶媒留去後, 水 $(100 \mathrm{~mL})$ を加え, ジクロ ロメタン $(100 \mathrm{~mL}$ で 2 回) で抽出した後, 溶媒を留去 した。残分をクーゲルロール蒸留 $\left(110^{\circ} \mathrm{C} / 0.03 \mathrm{mmHg}\right)$ し, エステル誘導体を得た。収量 $4.50 \mathrm{~g}$ 。収率 $72 \%$ 。 透明粘ちょう液体。次に, 得られたエステル誘導体 $(0.003 \mathrm{~mol}, 0.94 \mathrm{~g})$ をクロロホルム $(30 \mathrm{~mL})$ 溶液と し, 約 $0^{\circ} \mathrm{C}$ でかくはんしながら, クロロ硫酸 $(0.006$ $\mathrm{mol}, 0.70 \mathrm{~g})$ を $30 \mathrm{~min}$ かけて滴下し, さらに $2.5 \mathrm{~h}$ か くはんした。これに温度を $0^{\circ} \mathrm{C} に$ 保ったまま水酸化ナト リウム $(0.006 \mathrm{~mol}, 0.24 \mathrm{~g})$ のメタノール $(150 \mathrm{~mL})$ 溶 液, さらに炭酸ナトリウムを少量加えた後, メタノー ル, クロロホルムを留去した。残分に水 $(100 \mathrm{~mL})$ を 加え，1-ブタノール $(100 \mathrm{~mL}$ で 2 回 $)$ で抽出し, 硫酸 マグネシウム (無水物) で乾燥後, 1-ブタノールを留去 した。さらに水 $(70 \mathrm{~mL})$, メタノール $(30 \mathrm{~mL})$ を加 え, ヘキサン $(50 \mathrm{~mL}$ で 2 回) で洗浄し, 水, メタノー ルを留去することによって目的物 $4 \mathrm{~b}$ を得た。収量 $0.74 \mathrm{~g}$ 。収率 $43 \%$ (A-13 基準)。白色固体。

他の硫酸エステル塩型界面活性剂も同様の方法に準拠 して, 中間体のエステルアルコールをクーゲルロール蒸 留により精製した後, 硫酸エステル化を行い, 合成し た。原料カルボン酸基準の収率, 形状並びにスペクトル データを以下に記す。

(2 a) 収率 : $42 \%$; 白色ワックス状固体; IR : 1730 $\mathrm{cm}^{-1}\left(\nu_{\mathrm{C}=\mathrm{O}}\right) ; \mathrm{NMR}\left(\mathrm{CDCl}_{3}\right), \delta: 0.66 \sim 1.84(\mathrm{~m}, 29$ $\mathrm{H}), 3.91 \sim 4.21\left(\mathrm{~m}, 4 \mathrm{H},-\mathrm{COOCH}_{2}+-\mathrm{CH}_{2} \mathrm{OSO}_{3} \mathrm{Na}\right)$.

(2 b) 収率 : $39 \%$; 白色ワックス状固体; IR : 1730 $\mathrm{cm}^{-1}\left(\nu_{\mathrm{C}=\mathrm{O}}\right)$; NMR $\left(\mathrm{CDCl}_{3}\right), \delta: 0.68 \sim 1.90(\mathrm{~m}, 33$ $\mathrm{H}), 3.96 \sim 4.16\left(\mathrm{~m}, 4 \mathrm{H},-\mathrm{COOCH}_{2}+-\mathrm{CH}_{2} \mathrm{OSO}_{3} \mathrm{Na}\right)$.

(3 a) 収率： $41 \%$; 淡黄色ワックス状固体; IR : 1730 $\mathrm{cm}^{-1}\left(\nu_{\mathrm{C}=\mathrm{O}}\right) ; \mathrm{NMR}\left(\mathrm{CDCl}_{3}\right), \delta: 0.64 \sim 1.85(\mathrm{~m}, 29$ $\mathrm{H}), 4.00 \sim 4.32\left(\mathrm{~m}, 4 \mathrm{H},-\mathrm{COOCH}_{2}+-\mathrm{CH}_{2} \mathrm{OSO}_{3} \mathrm{Na}\right)$.

(3 b) 収率 : $43 \%$; 白色ワックス状固体; IR : 1720 $\mathrm{cm}^{-1}\left(\nu_{\mathrm{C}=\mathrm{O}}\right) ; \mathrm{NMR}\left(\mathrm{CDCl}_{3}\right), \delta: 0.76 \sim 1.72(\mathrm{~m}, 33$ $\mathrm{H}), 3.90 \sim 4.16\left(\mathrm{~m}, 4 \mathrm{H},-\mathrm{COOCH}_{2}+-\mathrm{CH}_{2} \mathrm{OSO}_{3} \mathrm{Na}\right)$.

(3 c) 収率： $49 \%$; 淡黄色ワックス状固体; IR : 1730 $\mathrm{cm}^{-1}\left(\nu_{\mathrm{C}=\mathrm{O}}\right) ; \mathrm{NMR}\left(\mathrm{CDCl}_{3}\right), \delta: 0.64 \sim 1.92(\mathrm{~m}, 37$ $\mathrm{H}), 4.00 \sim 4.28\left(\mathrm{~m}, 4 \mathrm{H},-\mathrm{COOCH}_{2}+-\mathrm{CH}_{2} \mathrm{OSO}_{3} \mathrm{Na}\right)$.

(4 a) 収率： $50 \%$; 白色にかわ状固 体; IR : 1740
$\mathrm{cm}^{-1}\left(\nu_{\mathrm{C}=\mathrm{O}}\right) ; \mathrm{NMR}\left(\mathrm{CDCl}_{3}\right), \delta: 0.64 \sim 2.60(\mathrm{~m}, 25$ $\mathrm{H}), 3.60 \sim 4.12\left(\mathrm{~m}, 4 \mathrm{H},-\mathrm{OCH}_{2}^{-}\right), 4.24 \sim 4.64(\mathrm{~m}, 4$ $\left.\mathrm{H},-\mathrm{COOCH}_{2}+-\mathrm{CH}_{2} \mathrm{OSO}_{3} \mathrm{Na}\right)$.

(4 b) 収率： $51 \%$; 白色にかわ状固体; IR : 1730 $\mathrm{cm}^{-1}\left(\nu_{\mathrm{C}=\mathrm{O}}\right) ; \mathrm{NMR}\left(\mathrm{CDCl}_{3}\right), \delta: 0.72 \sim 1.44(\mathrm{~m}, 25$ $\mathrm{H}), 3.64 \sim 3.96\left(\mathrm{~m}, 8 \mathrm{H},-\mathrm{OCH}_{2}^{-}\right), 4.11 \sim 4.48(\mathrm{~m}, 4$ $\left.\mathrm{H},-\mathrm{COOCH}_{2}+-\mathrm{CH}_{2} \mathrm{OSO}_{3} \mathrm{Na}\right)$.

（5）収率 : $29 \%$, 白色にかわ状固体; IR : $1740 \mathrm{~cm}^{-1}$ $\left(\nu_{\mathrm{C}=\mathrm{O}}\right) ; \mathrm{NMR}\left(\mathrm{CDCl}_{3}\right), \delta: 0.68 \sim 1.48(\mathrm{~m}, 34 \mathrm{H})$, $3.36 \sim 5.26(\mathrm{~m}, 9 \mathrm{H})$.

$2 \cdot 2 \cdot 4$ 第四級アンモニウム塩型カチオン界面活性剂 (6) の合成

Cl-13 (0.04 mol, $9.28 \mathrm{~g}$ ), 3-(ジメチルアミノ)-1-プ ロパノール $(0.08 \mathrm{~mol}, 8.24 \mathrm{~g})$ を混合し, $50^{\circ} \mathrm{C}$ で3 h か くはんした。これに水 $(150 \mathrm{~mL})$ を加え, ジクロロメ タン (150 mL で 2 回) で抽出した後, ジクロロメタン を留去した。残分をクーゲルロール蒸留 $\left(70^{\circ} \mathrm{C} / 0.05\right.$ $\mathrm{mmHg})$ し, 透明な液体として中間体エステル化合物 $(8.73 \mathrm{~g}, 73 \%)$ を得た。IR : $1730 \mathrm{~cm}^{-1}\left(\nu_{\mathrm{C}=\mathrm{O}}\right)$; NMR $\left(\mathrm{CDCl}_{3}\right), \delta: 0.80 \sim 1.16(\mathrm{~m}, 25 \mathrm{H}), 1.64 \sim 1.95(\mathrm{~m}, 2$ $\left.\mathrm{H},-\mathrm{COOCH}_{2} \mathrm{CH}_{2} \mathrm{CH}_{2}{ }^{-}\right), 2.24\left[\mathrm{~s}, 6 \mathrm{H},-\mathrm{N}\left(\mathrm{CH}_{3}\right)_{2}\right]$, 2.88 2.44[t, $\left.2 \mathrm{H},-\mathrm{CH}_{2} \mathrm{~N}\left(\mathrm{CH}_{3}\right)_{2}\right], 4.04 \sim 4.17(\mathrm{~m}$, $2 \mathrm{H},-\mathrm{COOCH}_{2}^{-}$).

次に得られたエステル誘導体 $(0.01 \mathrm{~mol}, 2.99 \mathrm{~g}), \exists$ ウ化メチル $(0.03 \mathrm{~mol}, 4.26 \mathrm{~g})$ を封管し, 時々振り混 ぜながら $80^{\circ} \mathrm{C}$ の水浴中で $3 \mathrm{~h}$ 反応させた。冷却後開封 し, ジクロロメタン $(50 \mathrm{~mL})$ で洗浄してなす型フラス コに移しかえ, 過剰のヨウ化メチル並びにジクロロメタ ンを留去した。薄黄色の固体としてほぼ定量的に対応す る第四級アンモニウム塩 $(6)$ を得た。IR : $1720 \mathrm{~cm}^{-1}$ $\left(\nu_{\mathrm{C}=\mathrm{O}}\right) ; \operatorname{NMR}\left(\mathrm{CDCl}_{3}\right), \delta: 0.84 \sim 1.20(\mathrm{~m}, 25 \mathrm{H})$, $2.16 \sim 2.40\left(\mathrm{~m}, 2 \mathrm{H},-\mathrm{COOCH}_{2} \mathrm{CH}_{2} \mathrm{CH}_{2}{ }^{-}\right), 3.56[\mathrm{~s}, 9$ $\left.\mathrm{H},-\mathrm{N}\left(\mathrm{CH}_{3}\right)_{3}\right], 3.72 \sim 3.88\left[\mathrm{~m}, 2 \mathrm{H},-\mathbf{C H}_{2} \mathrm{~N}\left(\mathrm{CH}_{3}\right)_{3}\right]$, $4.20 \sim 4.32\left(\mathrm{~m}, 2 \mathrm{H},-\mathrm{COOCH}_{2}^{-}\right)$.

$2 \cdot 2 \cdot 5$ 第四級アンモニウム塩型カチオン界面活性剤 (7) の合成

Cl-13 (0.04 mol, $9.28 \mathrm{~g})$ 及び溶媒として用いたジク ロロメタン $(10 \mathrm{~mL})$ を $70^{\circ} \mathrm{C}$ でかくはんしながら, $N, N$-ジメチルエチレンジアミン $(0.08 \mathrm{~mol}, 7.04 \mathrm{~g})$ を $30 \mathrm{~min}$ かけて滴下した。 $3 \mathrm{~h}$ 後冷却し, 炭酸ナトリウ 厶 $(0.06 \mathrm{~mol})$ 水溶液 $(150 \mathrm{~mL})$ を加え, ジクロロメ夕 ン (150 mL で 2 回) で抽出した後, ジクロロメタンを 留去した。残分をクーゲルロール蒸留 $\left(75^{\circ} \mathrm{C} / 0.04\right.$ $\mathrm{mmHg})$ し, 透明粘ちょうな液体として中間体アミド 化合物 $(9.54 \mathrm{~g}, 84 \%)$ を得た。 IR : $1640 \mathrm{~cm}^{-1}\left(\nu_{\mathrm{C}=\mathrm{O}}\right)$; NMR $\left(\mathrm{CDCl}_{3}\right), \delta: 0.84 \sim 1.16(\mathrm{~m}, 25 \mathrm{H}), 2.24[\mathrm{~s}, 6$ $\left.\mathrm{H},-\mathrm{N}\left(\mathrm{CH}_{3}\right)_{2}\right], 2.34 \sim 2.48\left[\mathrm{t}, 2 \mathrm{H},-\mathrm{CH}_{2} \mathrm{~N}\left(\mathrm{CH}_{3}\right)_{2}\right]$, $3.24 \sim 3.42\left(\mathrm{~m}, 2 \mathrm{H},-\mathrm{CONHCH}_{2}^{-}\right)$. 
上記アミド誘導体 $(0.015 \mathrm{~mol}, 4.26 \mathrm{~g})$, 塩化ベンジル $(0.017 \mathrm{~mol}, 2.16 \mathrm{~g})$ を混合し, $120^{\circ} \mathrm{C}$ で $5 \mathrm{~h}$ 反応した。 これにへキサン $(50 \mathrm{~mL}$ で 2 回) を加えデカンテーショ ンを行って不純物を除き, シリカゲルショートカラム (エタノール $100 \%$ ) で精製し，ほぼ定量的に目的物(7) を得た。IR : $1640 \mathrm{~cm}^{-1}\left(\nu_{\mathrm{C}=\mathrm{O}}\right) ; \mathrm{NMR}\left(\mathrm{CDCl}_{3}\right), \delta$ : $0.72 \sim 1.24(\mathrm{~m}, 25 \mathrm{H}), 3.36\left[\mathrm{~s}, 6 \mathrm{H},-\mathrm{N}\left(\mathrm{CH}_{3}\right)_{2}\right], 3.86$ (bs, $\left.4 \mathrm{H},-\mathrm{CONHCH}_{2} \mathrm{CH}_{2}\right), 4.92\left(\mathrm{~s}, 2 \mathrm{H},-\mathrm{CH}_{2} \mathrm{Ph}\right.$ ), $7.34 \sim 7.60\left(\mathrm{~m}, 5 \mathrm{H},-\mathrm{CH}_{2} \mathrm{Ph}\right)$.

$2 \cdot 2 \cdot 6$ ベタイン型両性界面活性剂 (8) の合成

$2 \cdot 2 \cdot 5$ で合成した中間生成物アミド誘導体 $(0.01 \mathrm{~mol}$, $2.84 \mathrm{~g})$, モノクロロ酢酸ナトリウム $(0.01 \mathrm{~mol}, 1.17$ $\mathrm{g})$, 水 $(1.5 \mathrm{~mL})$ を $95 \sim 100^{\circ} \mathrm{C}$ に保ち, 水は蒸発させな がら $3 \mathrm{~h}$ かくはんした。酢酸エチル $(40 \mathrm{~mL})$ を加え, 硫酸ナトリウム (無水物) $3 \mathrm{~g}$ で乾燥後, 温時沪過し, 不溶の結晶及び硫酸ナトリウムを除去し, 酢酸エチルを 留去した。淡黄色半透明の極めて粘ちょうな液体とし て，ほぼ定量的に目的物（8）を得た。IR：1650 $\mathrm{cm}^{-1}$ $\left(\nu_{\mathrm{C}=\mathrm{O}}\right) ; \mathrm{NMR}\left(\mathrm{CDCl}_{3}\right), \delta: 0.72 \sim 1.20(\mathrm{~m}, 25 \mathrm{H})$, $3.40\left[\mathrm{~s}, 6 \mathrm{H}, \mathrm{N}^{+}\left(\mathrm{CH}_{3}\right)_{2}\right], 3.80\left[\mathrm{bs}, 4 \mathrm{H},-\mathrm{CH}_{2} \mathrm{~N}^{+}\right.$ $\left(\mathrm{CH}_{3}\right)_{2}+-\mathrm{CONHCH}_{2-}$ ], 4.00 (bs, $2 \mathrm{H},-\mathrm{N}^{+} \mathrm{CH}_{2}$ $\mathrm{COO}^{-}$).

$2 \cdot 2 \cdot 7$ ポリ（オキシエチレン）型非イオン界面活性 剤 (9) の合成

エチレングリコール $(0.04 \mathrm{~mol}, 2.48 \mathrm{~g})$, トリエチル アミン $(0.08 \mathrm{~mol}, 8.08 \mathrm{~g})$, ジクロロエタン $(5 \mathrm{~mL})$ を 混合し, 還流条件下, Cl-13 (0.02 mol, $4.64 \mathrm{~g})$ のジク ロロエタン溶液 $(5 \mathrm{~mL})$ を $1 \mathrm{~h}$ かけて滴下し, さらに 4 $\mathrm{h}$ 還流した。溶媒留去後, 水 $(100 \mathrm{~mL}$ で 2 回) で抽出 し, ジクロロメタンを留去した。残分をクーゲルロール 蒸留 $\left(110^{\circ} \mathrm{C} / 0.03 \mathrm{mmHg}\right)$ し, 中間体エステル誘導体 を得た。収量 $3.97 \mathrm{~g}$ 。収率 $77 \%$ 。透明粘ちょう液体。 IR: $1730 \mathrm{~cm}^{-1}\left(\nu_{\mathrm{C}=\mathrm{O}}\right) ; \mathrm{NMR}\left(\mathrm{CDCl}_{3}\right), \delta: 0.76 \sim 1.24$ $(\mathrm{m}, 25 \mathrm{H}), 3.80 \sim 3.88\left(\mathrm{~m}, 2 \mathrm{H},-\mathrm{CH}_{2} \mathrm{OH}\right), 4.16 \sim$ $4.28\left(\mathrm{~m}, 2 \mathrm{H},-\mathrm{COOCH}_{2}^{-}\right)$.

次に得られたエステル誘導体 $(0.007 \mathrm{~mol}, 1.81 \mathrm{~g})$ と 水酸化カリウム $(85 \% ; 0.007 \mathrm{~mol}, 0.046 \mathrm{~g})$ を混合し, $110^{\circ} \mathrm{C}$ でかくはんしながらエチレンオキシドを $4 \mathrm{~h}$ 吹き 込んだ。これに水 $(100 \mathrm{~mL})$ を加え，1-ブタノール(100 $\mathrm{mL}$ で 2 回) で抽出した後, 1ーブタノールを留去した。 残分をクーゲルロール蒸留 $\left(120^{\circ} \mathrm{C} / 0.05 \mathrm{mmHg}\right) し$, 低沸点成分を除いた。収量 $2.10 \mathrm{~g}$ 。収率 $33 \%(\mathrm{~A}-13$ 基 準)。薄黄色粘ちょう液体。IR：1720 $\mathrm{cm}^{-1}\left(\nu_{\mathrm{C}=\mathrm{O}}\right)$; $\operatorname{NMR}\left(\mathrm{CDCl}_{3}\right), \delta: 0.76 \sim 1.12(\mathrm{~m}, 25 \mathrm{H}), 3.64$ (bs, $\left.41 \mathrm{H}, \quad-\mathrm{CH}_{2} \mathrm{CH}_{2} \mathrm{O}^{-}\right), \quad 4.12 \sim 4.28(\mathrm{~m}, 2 \mathrm{H},-\mathrm{COO}$ $\mathrm{CH}_{2-}^{-}$.

\section{$2 \cdot 3$ 界面物性の測定}

試料水溶液の表面張力は, Wilhelmy 式測定装置（島
津 ST-1) を用いたガラス吊板法により $20^{\circ} \mathrm{C}$ で測定し た。クラフト点 $\left(\mathrm{T}_{\mathrm{Kp}}\right)$ 及び罢り点 $\left(\mathrm{T}_{\mathrm{cp}}\right)$ は常法に従 い, 各試料 1 wt \% 水溶液で測定した。起泡力及び泡沫 安定性は $1 \mathrm{wt} \%$ 水溶液について半微量 TK 法光により $20^{\circ} \mathrm{C}$ で測定した。浸透力は, 内径 $30 \mathrm{~mm}$ の $100 \mathrm{~mL}$ メ スシリンダーにいれた所定濃度の試料溶液 $50 \mathrm{~mL}$ の液 面上においたフェルト片 (JIS-R $28 \mathrm{~W}$ 規格, $15 \mathrm{~mm} \times$ $15 \mathrm{~mm}$, ステンレスフック付き $70 \mathrm{mg}$ ) の沈降時間を測 定することにより評価した。

\section{3 結果及び考察}

本研究で合成した界面活性剂 (1９）は，いずれもい くつかの混合物からなる多分枝第三級カルボン酸のエス テルあるいはアミド誘導体であり, 詳細は実験項に記載 した。多分枝第三級カルボン酸誘導体の特長は, 第一級 あるいは第二級カルボン酸誘導体と比較してきわめて耐 加水分解性に優れている点である ${ }^{1)} 。$

合成した化合物の表面張力ー濃度曲線の代表例とし て, 硫酸エステル塩型化合物 $(2,3,4)$ の結果を Fig.-2 に示す。なお, 他の化合物もすべて上記曲線において明 確な屈曲点が認められた。界面活性剂の臨界ミセル濃度 $(\mathrm{cmc})$, 表面張力低下能 $\left(\gamma_{\mathrm{cmc}}\right)$ 及びクラフト点 $\left(\mathrm{T}_{\mathrm{Kp}}\right)$ をTable-1 に示す。エクアシッド 13 (A-13) のナトリ ウム塩はきわめて親水性が高く, $0.1 \mathrm{M}$ 以下の濃度では $\mathrm{cmc}$ が認められないため, このままでは界面活性剤と して不適である。従って, 疎水基と親水基の間に適当な

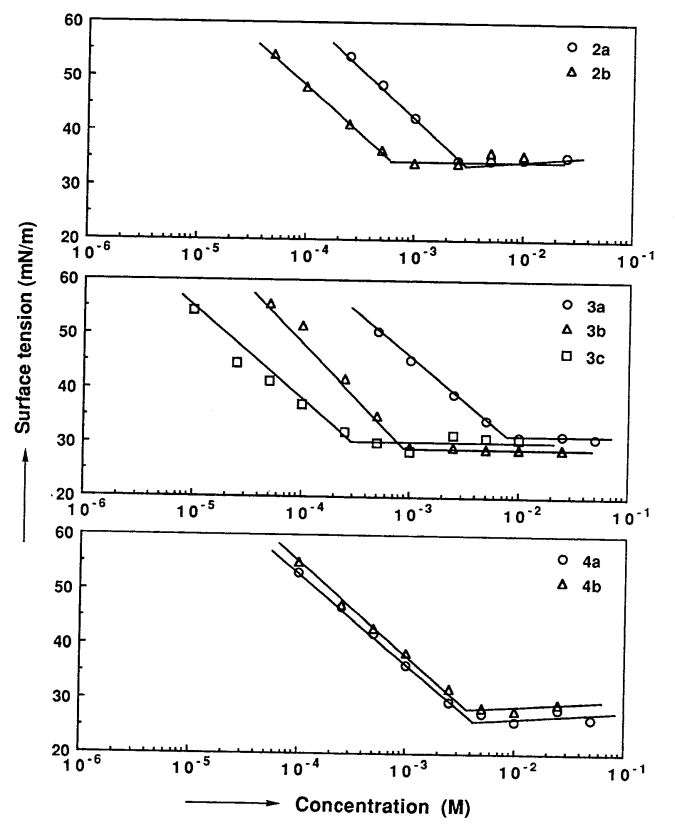

Fig. -2 Surface tension us concentration plots of surfactants 2, 3, and 4 . 
Table-1 The cmc, $\gamma_{\mathrm{cmc}}$ and $\mathrm{T}_{\mathrm{Kp}}$ values of compounds $1 \sim 10$.

\begin{tabular}{cccc}
\hline Surfactant & $\mathrm{cmc}(\mathrm{mM})$ & $\gamma_{\mathrm{cmc}}(\mathrm{mN} / \mathrm{m})$ & $\left.\mathrm{T}_{\mathrm{Kp}}{ }^{\mathrm{a}}\right)\left({ }^{\circ} \mathrm{C}\right)$ \\
\hline 1 & 20 & 29 & $<0$ \\
$2 \mathrm{a}$ & 3.0 & 33 & $<0$ \\
$2 \mathrm{~b}$ & 0.59 & 35 & $<0$ \\
$3 \mathrm{a}$ & 7.7 & 31 & $<0$ \\
$3 \mathrm{~b}$ & 0.93 & 29 & $<0$ \\
$3 \mathrm{c}$ & 0.28 & 30 & $<0$ \\
$4 \mathrm{a}$ & 4.1 & 26 & $<0$ \\
$4 \mathrm{~b}$ & 3.5 & 28 & $<0$ \\
5 & 1.3 & 30 & $<0$ \\
6 & 12 & 28 & $<0$ \\
7 & 17 & 29 & $<0$ \\
8 & 14 & 29 & $<0$ \\
9 & 0.086 & 31 & $<0$ \\
$10 \mathrm{a}^{\mathrm{b})}$ & 8.2 & 38 & 16 \\
$10 \mathrm{~b}^{\mathrm{c})}$ & $2.1\left(25^{\circ} \mathrm{C}\right)$ & $35\left(25^{\circ} \mathrm{C}\right)$ & 30 \\
$10 \mathrm{c}^{\mathrm{c})}$ & $0.58\left(40^{\circ} \mathrm{C}\right)$ & $37\left(60^{\circ} \mathrm{C}\right)$ & 45 \\
\hline
\end{tabular}

a) Krafft point b) ref. 4 c) ref. 5

連結基を導入することによって踈水性を向上させる必要 があると考えた。多分枝第三級カルボン酸のエステルあ るいはアミド結合は耐加水分解性が高いため, これらの 結合形成反応により簡単かつ安定な連結基を導入するこ とができる。比較的容易に入手でき，合成ステップ数を
少なくすることを念頭において, まず連結基部分の短い ものを選び, 親水基構造を変化させ, アニオン (1), カ チオン $(6,7)$, 両性 (8), 非イオン界面活性剂 (9) を合成 した。その結果, 非イオン界面活性剤を別にして, 連結 基がメチレン数 2 から 3 のもの $(1,6,7,8)$ では, いず れも $\mathrm{cmc}$ が 12 20 $\mathrm{mM}$ 程度と高いものの表面張力低 下能は $28 \sim 29 \mathrm{mN} / \mathrm{m}$ と大変優れていることがわかっ た。

単一成分の界面活性剤における飽和炭化水素疎水基構 造と $\mathrm{cmc}$ あるいは表面吸着の有効度などとの関係は, 桑村らによってかなり体系化されている6)。本研究では 混合物であることを踏まえた上で, この多分枝構造に基 づく疎水基の特徵を明らかにするため, 親水基を硫酸工 ステル塩 (2 5) に固定し, 連結基構造が界面物性に及 ぼす効果について検討した。A-13 由来の疎水基をもつ 界面活性剤 (3) の場合, 連結基のメチレン鎖長を 4 (3 a), 6 (3 b), 8(3 c) と増加させると当然ミセル形成能 は増大するが, このときクラフト点はいずれも $0^{\circ} \mathrm{C}$ 以下 で高い水溶性が維持されていることがわかった。もちろ ん, 直鎖型界面活性剂（10）の場合にも，疎水基を大き くすることにより $\mathrm{cmc}$ を下げることができるが, クラ フト点は上昇するため水溶性が問題亡なる。本研究の多 分枝型界面活性剤はいずれの場合も表面張力低下能は高 い。これは単一成分の多鎖型界面活性剂の表面吸着の有 効度は, 対応する構造の単鎖型に比べて大きいという ハートレイ効果 ${ }^{7)}$ と明確に対応している。また A-9 由

Table-2 Foaming properties and wetting ability of compounds $1 \sim 10$ and Aerosol OT.

\begin{tabular}{cccccc}
\hline \multirow{2}{*}{ Surfuctant } & \multicolumn{2}{c}{ Foam volume (mL) } & \multicolumn{4}{c}{ Wetting time (s) } \\
& 0 min & 5 min & 1 wt \% & 0.6 wt \% & 0.1 wt \% \\
\hline 1 & 100 & 0 & 4 & 13 & - \\
2 a & 240 & 60 & 7 & - & - \\
$2 \mathrm{~b}$ & 250 & 80 & 7 & - & 11 \\
3 a & 140 & 20 & 4 & - & - \\
$3 \mathrm{~b}$ & 260 & 260 & 4 & 4 & 5 \\
$3 \mathrm{c}$ & 260 & 260 & 4 & - & 6 \\
$4 \mathrm{a}$ & 240 & 140 & 3 & - & - \\
$4 \mathrm{~b}$ & 200 & 200 & 3 & - & - \\
5 & 250 & 0 & 2 & - & 8 \\
6 & 210 & 40 & 4 & 5 & - \\
7 & 100 & 0 & 5 & 9 & - \\
8 & 210 & 0 & 4 & 5 & - \\
9 & 240 & 20 & 4 & 4 & 6 \\
10 a & 250 & 70 & 14 & 30 & - \\
Aerosol OT & - & - & - & - & $5^{\mathrm{a})}$ \\
\hline
\end{tabular}

a) Sodium 1,2-bis[(2-ethylhexyl)oxycarbonyl]-1-ethanesulfonate; ref. 11 
来の界面活性剂 (2) と A-13 由来の界面活性剂（3）につ いて, 分子量が同じである場合 $(2 \mathrm{a}$ と $3 \mathrm{a}$ あるいは $2 \mathrm{~b}$ と $3 \mathrm{~b}$ ) には, 連結基の直鎖部位の長い界面活性剂 (2) の方がミセル形成能に優机ており, 一方, 表面張力低下 能は主鎖部分が大きい界面活性剤 (3) の方が優れてい る。これらの結果は, いずれの界面活性剂も直鎖の連結 基をもつものの，A-13 から誘導された界面活性剤 (3) は A-9 から誘導された界面活性剂 (2) に比べ分枝部分 の寄与が大きいことによるものと考えられる。すなわ ち, 同じく分枝構造をもつものであっても，このように 化合物 (2) 亡 (3) で微妙に分枝の大きさの差が反映され ておりきわめて興味深い。また，オキシエチレン単位を 連結基として用いることによってもミセル形成能を高め ることができる。こ扎はイオン性基の近傍のエーテル酸

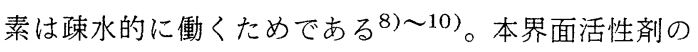
場合にも化合物（3 a) に比べ化合物（4 a) あるいは (4 b) の方が低い cmcを示した。

界面活性剂の起泡力, 泡沫安定性並びに浸透力の結果 を Table-2 に示す。連結基の短い一部のもの $(1,3 \mathrm{a}$, 7）を除き，おおむね起泡力は良好であるが, 泡沫安定 性にはかなり差が認められる。直鎖型（10 a) に比べ, 浸透力は $\mathrm{cmc}$ 以上の濃度ではいずれの界面活性剤も良 好であるが, 特に, 界面活性剤 (3b) 及び (3 c) が市販 の浸透剤として広く用いられているAerosol OT に匹 敵する浸透力を示したことは特筆される。A-9 由来の ものと A-13 由来のものを比較した場合 $(2 \mathrm{a}$ と $3 \mathrm{a}$ ある いは $2 \mathrm{~b}$ と $3 \mathrm{~b})$, 前述したように $\mathrm{cmc} や \gamma_{\mathrm{cmc}}$ に対して 分枝構造の寄与の大きいことが見いだされた A-13 由来 のものの方が高い浸透力を示すことがわかった。これも 浸透力に与える枝分かれの程度の差を明確に反映してい る結果と考えられる。

\section{4 結 論}

多分枝第三級カルボン酸をビルディングブロックとし て, そのエステル誘導体の高い耐加水分解性を活用し,
適当な連結基をはさんで親水基を導入することにより， 表面張力低下能に優れ, 水溶性の良好なア二オン界面活 性剂を合成した。典型的な分枝型界面活性剂である構造 上の特徵に着目して疎水基部分の構造を系統的に变化さ せることにより, 当該界面活性剤の疎水基部分の枝分か れの程度が增すと，ミセル形成能は若干低下するもの の, 界面張力低下能並びに浸透力が向上することを明ら かにした。一方，非イオン界面活性剤である多分枝第三 級カルボン酸ポリ(オキシエチレン) エステル (9) は化 学安定性はもちろんのこと, ミセル形成能, 表面張力低 下能, 浸透力ともに優れており, 合成も容易であること からノニルフェノールのエチレンオキシド付加物と同様 の用途が期待される。

〔平成 4 年 (1992 年) 2 月 19 日受理〕

$$
\text { 文献 }
$$

1）相馬芳枝, 佐野 寛, 三輪秀明, 川崎 宏, 市原 収, 有合化, 48, 92 (1990)

2) 川崎 宏, 市原 収, 公開特許, 昭和 64-3145

3) 矢野 弥, 木村和三郎, 油化学, 11, 138 (1962)

4) Y-p. Zhu, A. Masuyama, Y. Kirito, M. Okahara, M.J. Rosen, J. Am. Oil Chem. Soc., 69, 626 (1992)

5) M.J. Rosen, "Surfactants and Interfacial Phenomena", 2nd ed., John Wiley \& Sons, N.Y. (1989), p. $123,126,220$

6）桑原常彦, “界面活性剂”, 北原文雄, 玉井康勝, 早野 茂夫, 原一郎編, 講談社 (1979) p. 10

7) G.S. Hartley, Trans. Faraday Soc., 37, 30 (1941)

8) J.K. Weil, R.G. Bistline, A.J. Stirton, J. Phys. Chem., 62, 1083 (1958)

9) D.S. Murphy, Z.H. Zhu, X.Y. Yuan, M.J. Rosen, J. Am. Oil Chem. Soc., 67, 197 (1990)

10) Y-p. Zhu, A. Masuyama, M. Okahara, J. Am. Oil Chem. Soc., 68, 268 (1991)

11) Y-p. Zhu, A. Masuyama, M. Okahara, J. Am. Oil Chem. Soc., 67, 459 (1991) 